\title{
Quality of life and associated factors in non-institutionalized elderly: a cross-section
}

\section{study}

Qualidade de vida e fatores associados em idosos não institucionalizados: um estudo transversal

Calidad de vida y factores asociados en ancianos no institucionalizados: un estudio transversal

Michele Natara Portilio

ORCID: https://orcid.org/0000-0002-3169-9470 Faculty Meridional, Brazil

E-mail: michelenatara@gmail.com

Maitê Piazza Willig

ORCID: https://orcid.org/0000-0001-9522-969X Faculty Meridional, Brazil

E-mail: maite.radiolab@gmail.com

Maete Cavalheiro

ORCID: https://orcid.org/0000-0001-6407-8534 Faculty Meridional, Brazil

E-mail: maetecavalheiro@yahoo.com.br

Tiago Cadore da Motta

ORCID: https://orcid.org/0000-0002-6261-0205 Faculty Meridional, Brazil

E-mail: tiagocadore@gmail.com

Lilian Rigo

ORCID: https://orcid.org/0000-0003-3725-3047

Faculty Meridional, Brazil

E-mail: lilian.rigo@imed.edu.br

\begin{abstract}
The aim this study was to analyze the quality of life (QoL) and its the association with sociodemographic and oral health data in non-institutionalized elderly individuals. This is a cross-sectional study with a sample of 225 elderly individuals aged 60 years or older from a city in Southern Brazil. For data collection, we used the quality of life scale (WHOQOL-OLD), the Geriatric Oral Health Assessment Index (GOHAI), as well as questions about sociodemographic and oral health conditions. QoL presented a mean of 62.73. Sociodemographic variables were tested in a linear regression model, and those that remained associated in the final adjusted model were: age ( $\beta=-$ $0.25 ; 95 \%$ confidence interval, CI: $-0.40 ;-0.14)$, daily independence $(\beta=-0.32 ; 95 \%$ CI: $-7.71 ;-3.57)$, and participation in social activities $(\beta=-0.12 ; 95 \%$ CI: $-4.31 ;-0.21)$. The elderly individuals' oral characteristics were compared, and the following remained associated in the adjusted model: time of last visit to the dentist $(\beta=-0.34$; $95 \%$ CI: $-9.50 ;-4.65)$ and oral self-perception ( $\beta=0.30 ; 95 \%$ CI: $0.53 ; 1.18)$. The findings of this study showed that, being older, being dependent in life and non-participating in social activities, as well as no visiting the dentist last year were predictors of a worst QoL for the elderly, however, good self-perception of oral health was a predictor of better QoL.
\end{abstract}

Keywords: Quality of life; Elderly; Oral health; Health of the elderly; Self perception.

\section{Resumo}

O objetivo deste estudo foi analisar a qualidade de vida (QV) e sua associação com dados sociodemográficos e de saúde bucal em idosos não institucionalizados. Trata-se de um estudo transversal com amostra de 225 idosos com 60 anos de idade ou mais moradores de uma cidade do Sul do Brasil. Para a coleta de dados foram utilizadas a escala de qualidade de vida (WHOQOL-OLD), o Índice de Avaliação de Saúde Bucal Geriátrica (GOHAI), além de questões sobre condições sociodemográficas e de saúde bucal. A QV apresentou média de 62,73. As variáveis sociodemográficas foram testadas em modelo de regressão linear e as que permaneceram associadas no modelo final ajustado foram: idade $(\beta=-0,25$; IC95\% $-0,40 ;-0,14)$, independência diária $(\beta=-0,32$; IC95\% -7,71; $-3,57)$ e participação em atividades sociais $(\beta=-0,12$; IC95\% $-4,31 ;-0,21)$. As características orais dos idosos foram comparadas e permaneceram associadas no modelo ajustado: tempo da última consulta ao dentista ( $\beta=-0,34$; IC95\% $-9,50 ;-4,65)$ e autopercepção oral $(\beta=0,30$; IC95\% 0,$53 ; 1,18)$. Os achados deste estudo mostraram que ser mais velho, ser dependente na vida e não participar de atividades sociais, bem como não ter ido ao dentista no ano passado foram preditores de pior QV, contudo, uma boa autopercepção da saúde bucal foi preditor de melhor QV. 
Palavras-chave: Qualidade de vida; Idosos; Saúde bucal; Saúde dos idosos; Autopercepção.

\section{Resumen}

El objetivo fue analizar la calidad de vida (CV) y su asociación con datos sociodemográficos y de salud bucal en ancianos no institucionalizados. Se trata de un estudio transversal con una muestra de 225 ancianos de 60 años o más de una ciudad del sur de Brasil. Para la recolección de datos utilizamos la escala de calidad de vida (WHOQOLOLD), el Índice de Evaluación de Salud Oral Geriátrica (GOHAI), así como preguntas sobre condiciones sociodemográficas y de salud bucal. La CV presentó una media de 62,73. Las variables sociodemográficas se probaron en un modelo de regresión lineal, y las que quedaron asociadas en el modelo final ajustado fueron: edad ( $\beta=$ $-0,25$; intervalo de confianza del $95 \%$, IC95\%-0,40; $-0,14)$, independencia diaria $(\beta=-0,32$; IC95\% -7,71; $-3,57)$ y participación en actividades sociales $(\beta=-0,12$; IC95\% $-4,31 ;-0,21)$. Se compararon las características orales de los ancianos, permaneciendo asociadas en el modelo ajustado: tiempo de la última visita al dentista ( $\beta=-0,34$; IC95\% $9,50 ;-4,65)$ y autopercepción oral $(\beta=0,30$; IC95\% 0,$53 ; 1,18)$. Los hallazgos de este estudio mostraron que ser mayor, ser dependiente en la vida y no participar en actividades sociales, así como no visitar al dentista el año pasado fueron predictores de una peor CV, todavía, una buena autopercepción de la salud bucal fue un predictor de una mejor calidad de vida.

Palabras clave: Calidad de vida; Ancianos; Salud bucal; Salud de los ancianos; Autopercepción.

\section{Introduction}

Quality of life (QoL) is defined by the World Health Organization (WHO) as "the individual's perception of their position in life in the context of the culture and value systems in which they live and in relation to their goals" (The Whoqol Group, 1995). Moreover, QoL in the aging process is not only a neutral description of life, it is also a judgment about the life desirability level and the conditions surrounding it (Boggatz, 2016). After increase of age, there is loss of cognitive abilities that result in physical changes, making the person more debilitated and socially inactive, but these are not the only points that can affect the elderly's well-being (Borglin, Jakobsson, Edberg, \& Hallberg, 2006). Studies show that QoL can also be influenced by sociodemographic characteristics, such as gender, age, education, economic status, and individual disabilities (Lebrão \& Laurenti, 2005).

In addition, negative experiences with previous medical and dental treatments, clinical oral health conditions and access to health are points that interfere with the elderly's daily activities (Bulgareli et al., 2018). The elderly may also have other debilitating systemic conditions, which may compromise the degree of autonomy, independence and, consequently, affect the QoL (Moreira, Nico \& Sousa 2009).

There are several scales to assess QoL, however, due to the age of the population analyzed in this study, we assumed to be more appropriate to use an instrument that covers a cross-cultural perspective and also considers the subjective character of QoL (Fleck, Louzada, Xavier, Chachamovich \& Vieira Santos, 2000). Therefore, the World Health Organization QoL (WHOQOL-OLD) instrument became essential for such purpose (Fleck, 2003).

Thus, we need to understand the aging process multifactoriality (Melo, Eutálio, Silva, Silva-Filho \& Gonzaga, 2013). Therefore, relevant studies have been investigating the influence of various aspects on QoL, which are important in the healthy aging process.

The purpose of this study was to analyze the QoL and its association with sociodemographic and oral health data in non-institutionalized elderly individuals from a city in Southern Brazil.

\section{Methodology}

\section{Design and sampling}

The study was submitted to the Research Ethics Committee of Faculty Meridional (IMED) and was approved under protocol number 2,276,838 and CAAE 75539417.2.0000.5319 on September 15, 2019. 
This is a quantitative and cross-sectional study. We followed the recommendations of the Strengthening the Reporting of Observational Studies in Epidemiology (STROBE) (Malta, Cardoso, Bastos, Magnanini \& Silva, 2010). The sample consisted of elderly non-institutionalized individuals aged 60 years or older who lived in a city in Southern Brazil and traveled through the only central square of the city, which is located in the center and is the passage of all residents between the months in which data were collected (September to December 2019).

Inclusion criteria were elderly individuals aged 60 years or older, both genders, older people without a severe cognitive impairment, who willingly accepted to participate in the research and lived in the city of Marau, Rio Grande do Sul State, Brazil.

According to Brazilian Institute of Geography and Statistics (IBGE, 2018), 3,964 individuals is the total population of elderly individuals aged 60 years or older, belonging to the city of Marau. For the sample calculation to be representative of this population, we applied an $85 \%$ confidence level, a 5\% margin of error, a 50\% probability of outcome, and a calculated sample size of 198 elderly individuals. By adding other $10 \%$ due to possible losses, the final calculated sample was 227 individuals. Considering that two individuals $(0,8 \%)$ did not accept to participate in the research, the sample of this investigation was comprised of 225 elderly individuals (99,2\% participation of the total sample).

\section{Study location}

The city of Marau is in the North of Rio Grande do Sul State, south of Brazil, with an area of 650 square kilometers. It was colonized by Italian immigrants in 1904. The last Instituto Brasileiro de Geografia e Estatística census found 36,364 people inhabiting the city (IBGE, 2018). The exact collection was in the central region of the city, in the only central square.

\section{Data collection}

The evaluator participated in a training consisting of theoretical explanations and practical simulation of data collection, and the pilot trial was performed on 20 elderly individuals. After the collection for the test, the questionnaires were analyzed and some questions were reorganized, in order to improve understanding in their completion. The research was a result of a self-administered questionnaire that was applied four times a week in the afternoon shifts, during five months at the established collection site.

The questions that were used for the research were extracted from validated instruments:

- Questions on the elderly's QoL - WHOQOL-OLD, which aims to test and evaluate the QoL for older people and consists of 24 Likert scale items assigned to six facets:

Facet I - "Sensory Functioning" (SF) - evaluates functioning and impact of the loss of sensory skills on activities of daily living and the ability to interact with others on QoL.

Facet II - "Autonomy" (AUT) - refers to independence in old age, describing the extent to which one is able to make their own decisions and live autonomously.

Facet III - "Past, Present, and Future Activities" (PPF) - regards past, present, and future activities, describing future yearning projects and the satisfaction of life achievements and things they yearn for.

Facet IV - "Social Participation" (SP) - refers to social participation, which outlines participation in daily activities, especially in the community in which it operates.

Facet V - "Death and Dying (DD) - related to concerns, expectations, and fears about death and dying.

Facet VI - "Intimacy" (INT) - refers to intimacy, which assesses the ability to have personal and intimate relationships. 
Each facet has four questions; therefore, the score of possible values can range from 4 to 20 for all of them. Items are answered on a five-point scale, ranging from 1 (None) to 5 (Full). The scores of these six facets, or the values of the 24 items, can be combined to produce an overall ("global") score, which has been denoted as the "total score" for QoL in older adults. 13

In this study, there was a transformation from a raw score to a transformed scale score between 0 and 100, which made it possible to express the scale score in percentage, between the lowest possible value (0) and the highest possible (100), applying a statistical transformation formula.13 Thus, the quality assessment is classified as very bad (from 0 to 24), bad (from 25 to 49), neither bad nor good (from 50 to 74), good (from 75 to 90) and very good (91-100).

- $\quad$ Socio-dental issues of oral health perception - GOHAI (Geriatric Oral Health Assessment Index), which allows one to understand the functioning ability of an individual throughout his/her routine and the way he/she understands his/her well-being that determines the demand for dental treatments, and also allows to evaluate self-perception in oral health. The instrument consists of 12 questions related to the influence of oral health problems in three dimensions: physical, psychosocial and pain or discomfort (Mrtin, Barreto \& Pordeus, 2009; Atchinson \& Dolan, 1990).15 Physical function is represented by speech, chewing, and swallowing patterns. Psychosocial function is represented by concern with oral health, satisfaction or dissatisfaction with appearance, avoiding social contact due to oral problems and self-awareness about oral health (Carvalho, Manso, Salvado \& Nunes, 2013). The values for the self-perception classification of the GOHAI index are high (34-36 points), moderate (30-33 points), and low (<30 points).

- Sociodemographic questions - 16 sociodemographic and oral health questions were developed: "Age", "Gender", "Marital status", "Who is the head of household?", "How many people live in your household?", "Is there a dental element in your mouth?", "Is there a problem with your gum teeth?", "How do you think your teeth and gums are?", "Do you have dental prosthesis", "If so, how are you satisfied with it?", "If not, what is the reason for not having it?", "How do you depend on it on your daily activities?", "Do you participate in any associative/social activities clubs and /or gym?", "Did you receive any information about taking care of your mouth?", "Taking care of your mouth is important for your health. When was your last visit to the dentist?", "Do you have any systemic diseases?", and "Which ones?".

\section{Data analysis}

Data were organized in Excel spreadsheets and exported to the statistical package IBM SPSS ${ }^{\mathrm{TM}}$ (Statistical Package for the Social Sciences) program, version 20.0, Armonk, New York, United States.

We used absolute and relative frequency, mean, standard deviation, coefficient of variation, minimum and maximum values for descriptive statistics. To verify whether the independent variables were able to predict a better or worse QoL, the simple linear regression test and the multiple linear regression test were used, which are two models with different groups of exposure variables, but both with the same outcome for QoL.

All associations that had $\mathrm{P}<0.20$ in the simple analysis were included in the adjusted model with all variables. Only those with $\mathrm{P}<0.05$ after the final adjustment were statistically significant.

\section{Results}

\section{Descriptive analysis}

Table 1 describes the results of sociodemographic variables. One hundred and seventeen (52\%) individuals were aged between 60 and 70 years $(M=71.8$, standard deviation, $\mathrm{SD}=7.66$, minimum value $=60$ and maximum value $=90), 141(62$, $7 \%$ ) were female, 50.7\% were married, $124(55.1 \%)$ reported being totally independent in their activities, and $137(60.7 \%)$ did 
Research, Society and Development, v. 10, n. 2, e42310212645, 2021

(CC BY 4.0) | ISSN 2525-3409 | DOI: http://dx.doi.org/10.33448/rsd-v10i2.12645

not participate in associative activities.

Table 1. Distribution of sociodemographic variables of non-institutionalized elderly individuals from Marau (RS), Brazil, 2019 $(\mathrm{n}=225)$.

\begin{tabular}{|c|c|c|}
\hline Variable & $\mathbf{n}$ & $\%$ \\
\hline \multicolumn{3}{|l|}{ Age } \\
\hline 60 to 70 years & 117 & 52.0 \\
\hline 71 years or older & 108 & 48.0 \\
\hline \multicolumn{3}{|l|}{ Sex } \\
\hline Male & 84 & 37.3 \\
\hline Female & 141 & 62.7 \\
\hline \multicolumn{3}{|l|}{ Marital status } \\
\hline Single, widowed, and divorced & 111 & 49.3 \\
\hline Married & 114 & 50.7 \\
\hline \multicolumn{3}{|l|}{ Who is the head in your family? } \\
\hline Spouse & 55 & 24.4 \\
\hline Himself/herself & 133 & 59.2 \\
\hline Daughter/Son & 33 & 14.7 \\
\hline $\begin{array}{l}\text { Son-in-law/Daughter-in-law/Mother/ } \\
\text { Granddaughter }\end{array}$ & 3 & 1.2 \\
\hline \multicolumn{3}{|l|}{ How many people live in your house? } \\
\hline 1 to 3 & 158 & 70.2 \\
\hline 4 to 7 & 67 & 29.8 \\
\hline \multicolumn{3}{|l|}{ How do you depend on daily activities? } \\
\hline Totally independent & 124 & 55.1 \\
\hline Fully or partially dependent & 101 & 44.9 \\
\hline \multicolumn{3}{|l|}{$\begin{array}{l}\text { Do you participate in social activities - clubs } \\
\text { and/or gym? }\end{array}$} \\
\hline Yes & 88 & 39.1 \\
\hline No & 137 & 60.7 \\
\hline
\end{tabular}

Source: Authors.

Table 2 describes results regarding oral health, in which 174 (77.3\%) survey participants visited their dentist for over a year, $92(40.9 \%)$ believe that the condition of their teeth and gums is poor, and $158(70.2 \%)$ of the elderly have a systemic disease. 
Research, Society and Development, v. 10, n. 2, e42310212645, 2021

(CC BY 4.0) | ISSN 2525-3409 | DOI: http://dx.doi.org/10.33448/rsd-v10i2.12645

Table 2. Distribution of variables regarding oral health conditions and presence of systemic disease of non-institutionalized elderly individuals from Marau (RS), Brazil, $2019(\mathrm{n}=225)$.

\begin{tabular}{|c|c|c|}
\hline Variable & $\mathbf{n}$ & $\%$ \\
\hline \multicolumn{3}{|l|}{ Is there a dental element in your mouth? } \\
\hline Yes & 152 & 67.6 \\
\hline No & 73 & 32.4 \\
\hline \multicolumn{3}{|l|}{ Is there a problem with your teeth? } \\
\hline Yes & 80 & 35.6 \\
\hline No & 145 & 64.5 \\
\hline \multicolumn{3}{|l|}{ Is there a problem with your gums? } \\
\hline Yes & 34 & 15.1 \\
\hline No & 191 & 84.9 \\
\hline \multicolumn{3}{|l|}{ Do you think your teeth and gums? } \\
\hline Good & 67 & 29.7 \\
\hline Bad & 158 & 70.2 \\
\hline \multicolumn{3}{|l|}{ Do you have a prosthesis? } \\
\hline Yes & 156 & 69.3 \\
\hline No & 69 & 30.7 \\
\hline \multicolumn{3}{|l|}{ If yes, what is your degree of satisfaction? } \\
\hline Excellent & 2 & 9 \\
\hline Good & 55 & 24.4 \\
\hline Regular & 63 & 28.0 \\
\hline $\mathrm{Bad}$ & 25 & 11.1 \\
\hline Very bad & 11 & 13 \\
\hline \multicolumn{3}{|l|}{ If not, why not: } \\
\hline I do not need to, I chew very well & 8 & 3.6 \\
\hline It is too expensive & 26 & 11.6 \\
\hline I have no opinion about it & 35 & 15.5 \\
\hline \multicolumn{3}{|l|}{$\begin{array}{l}\text { Have you received any information about } \\
\text { mouth care? }\end{array}$} \\
\hline Yes & 175 & 77.8 \\
\hline No & 50 & 22.2 \\
\hline \multicolumn{3}{|l|}{ Is mouth care important for body health? } \\
\hline $\begin{array}{l}\text { Yes, because the mouth is associated with } \\
\text { the body health }\end{array}$ & 146 & 64.9 \\
\hline $\begin{array}{l}\text { No, because the mouth is not associated with } \\
\text { the rest of the body }\end{array}$ & 79 & 35.1 \\
\hline \multicolumn{3}{|l|}{ When was your last visit to the dentist? } \\
\hline Less than a year ago & 51 & 22.7 \\
\hline Over a year ago & 174 & 77.3 \\
\hline \multicolumn{3}{|l|}{ Do you have any systemic diseases? } \\
\hline Yes & 114 & 50.7 \\
\hline No & 111 & 49.3 \\
\hline
\end{tabular}

Source: Authors. 
The GOHAI questionnaire results presented a low self-perception in oral health of the elderly, with a general mean of $25(\mathrm{n}=209 ; 92.9 \%)$, followed by moderate $13(5.8 \%)$ and high self-perception $(1.3 \%)$.

Table 3 shows the results regarding the scores of the six facets/domains of the instrument and the total QoL score of the elderly, attributed by the mean, standard deviation, and variance. The higher the value, the better the elderly's QoL.

Table 3. Measurements of scores (mean and standard deviation) from the quality of life assessment and facets (mean, standard deviation and variance), according to the WHOQOL-OLD of non-institutionalized elderly individuals from Marau (RS), Brazil, 2019.

\begin{tabular}{lcc}
\hline Variable & Average & Standard deviation \\
\hline Sensory functioning & 62.58 & 12.93 \\
Autonomy & 72.02 & 12.97 \\
Past, Present, and Future Activities & 64.00 & 10.38 \\
Social Participation & 62.31 & 11.77 \\
Death and dying & 72.02 & 18.00 \\
Intimacy & 61.00 & 14.20 \\
\hline WHOQOL-OLD & & 8.56 \\
\hline
\end{tabular}

Source: Authors.

Regarding the overall WHOQOL-OLD average, most elderly individuals considered their overall QoL as "neither good nor bad" $(\mathrm{M}=62.73, \mathrm{SD}=8.56)$. The Autonomy, Death and Dying facets had higher quality scores $(\mathrm{M}=72.02, \mathrm{SD}=$ 12.97; $\mathrm{M}=72.02, \mathrm{SD}=18.0$, respectively). The Past, Present and Future Activities facet presented the highest average $(\mathrm{M}=$ 64.0, SD = 10.38). Sensory Functioning and Social Participation had lower but similar averages $(\mathrm{M}=62.58, \mathrm{SD}=12.93, \mathrm{M}=$ $62.31, \mathrm{SD}=11.77$, respectively). However, the lowest score was the Intimacy facet $(\mathrm{M}=61, \mathrm{SD}=14.20)$.

\section{Linear regression}

All sociodemographic variables and QoL were tested in the first model, but the multiple model included only the variables that had $\mathrm{P}<0.20$ : age, marital status (single/widowed/divorced and married), number of people living in the same household, head of household (spouse, he/she and children/grandchildren), daily dependence (totally independent and partially or totally dependent), social activities (categories: yes and no practice), systemic diseases (yes and no). The gender variable was not included in the final model $(\mathrm{P}>0.20)$. However, those that remained associated in the multiple final model were only: age, daily dependence and social activities $(\mathrm{P}<0.05)$. Therefore, the older age $(\beta=-0.25 ; 95 \% \mathrm{CI}:-0.40 ;-0.14)$, the greater the elderly's dependence on daily activities $(\beta=-0.32 ; 95 \% \mathrm{CI}:-7.71 ;-3.57)$ and non-participation in social activities $(\beta=-0.12$; 95\% CI: $(-4.31 ;-0.21)$, the worse the elderly's QoL. Moreover, these results show how much, in percentage, the variables explain QoL, age (25\%), dependence on daily activities (32\%), and participation in social activities (12\%), as seen in Table 4 . 
Table 4. Model 1 - Simple and multiple linear regression between sociodemographic variables and quality of life in noninstitutionalized elderly individuals, Marau (RS), Brazil, 2019.

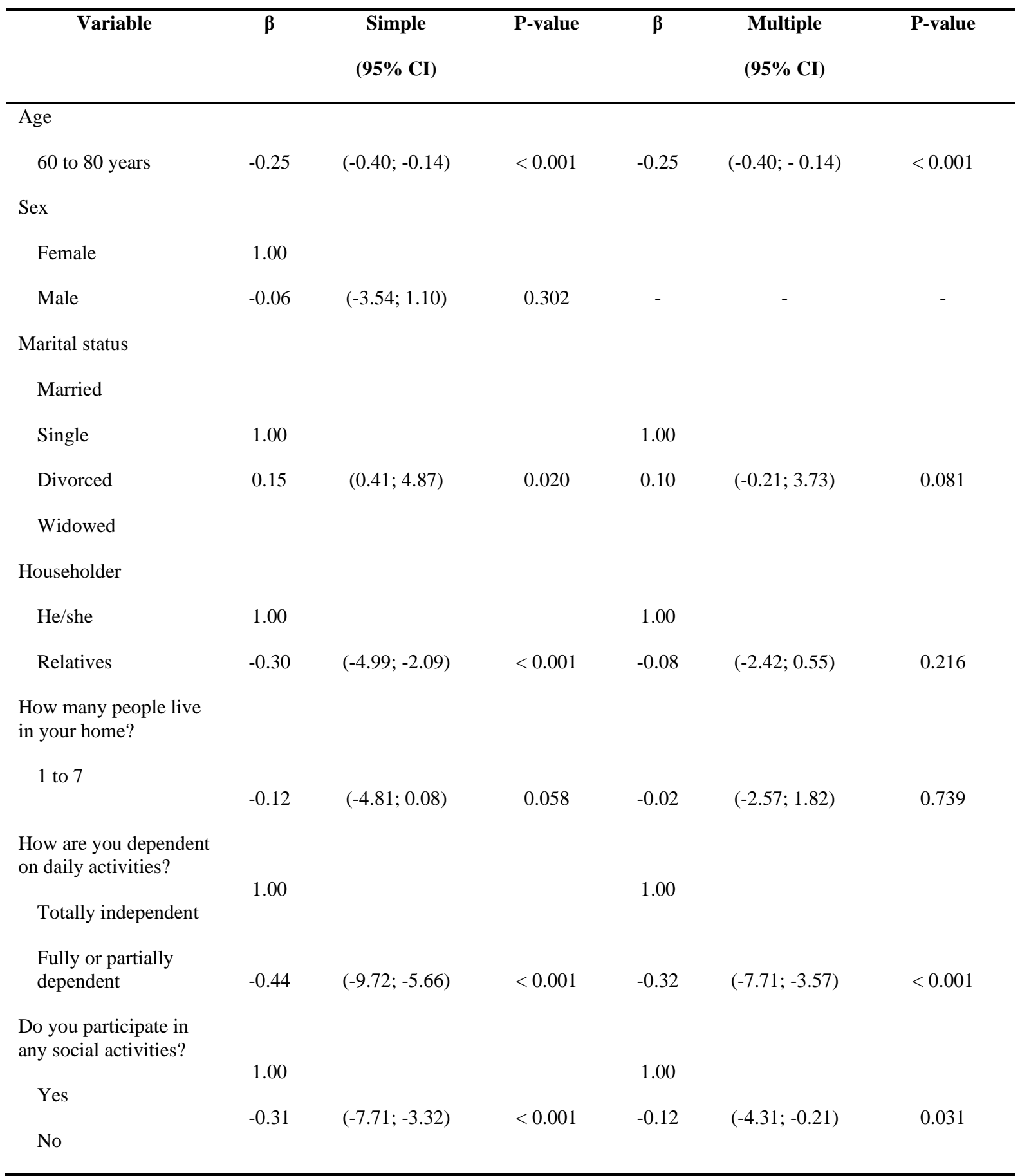

$\beta=$ correlation coefficient; $95 \% \mathrm{CI}=95 \%$ confidence interval. Adjusted for the variables: Age, marital status, head of household, how many people live in the household, dependence on daily activities, and participation in some social activities. Source: Authors.

All variables regarding oral health conditions and QoL were tested in the second model, including those with $\mathrm{P}<0.20$ in the adjusted model: edentulous (yes and no), uses dental prosthesis (yes and no), received information to take care of the mouth (yes and no), time of last appointment with the dentist (less than 1 year, more than 1 year), and oral self-perception GOHAI, using "enter" method. However, the ones that remained associated in the adjusted final model were only: time of the last appointment with the dentist and oral self-perception - GOHAI $(\mathrm{P}<0.05)$. Therefore, the lower the frequency of the visit 
to the dentist $(\beta=-0.34 ; 95 \% \mathrm{CI}:-9.50 ;-4.65)$, the worse the QoL; whereas the better the oral self-perception $(\beta=0.30 ; 95 \%$ CI: $0.53 ;-1.18)$, the better the QoL. Thus, the frequency of the visit to the dentist explains 34\% of QoL and 30\%, selfperception (Table 5).

Table 5. Model 2 - Simple and multiple linear regression between the variables of oral health conditions and quality of life in non-institutionalized elderly individuals, Marau (RS), Brazil, 2019.

\begin{tabular}{|c|c|c|c|c|c|c|}
\hline Variable & $\beta$ & Simple $(95 \%$ CI) & P-value & $\beta$ & $\begin{array}{l}\text { Multiple } \\
(95 \% \text { CI) }\end{array}$ & P-value \\
\hline \multicolumn{7}{|c|}{$\begin{array}{l}\text { Do you have a dental } \\
\text { element in your } \\
\text { mouth? }\end{array}$} \\
\hline Yes & 1.00 & & & & & \\
\hline No & -0.19 & $(-5.88 ;-1.15)$ & 0.004 & 0.02 & $(-2.14 ; 3.08)$ & 0.722 \\
\hline \multicolumn{7}{|c|}{$\begin{array}{l}\text { Do you have a dental } \\
\text { prosthesis? }\end{array}$} \\
\hline \multicolumn{7}{|l|}{ No } \\
\hline res & -0.24 & $(-6.98 ;-2.24)$ & $<0.001$ & -0.12 & $(-5.09 ; 0.32)$ & 0.084 \\
\hline
\end{tabular}

$\begin{aligned} & \text { Did you get any } \\ & \text { information on how to } \\ & \text { take care of your } \\ & \text { mouth? }\end{aligned}$
$\quad 1.00$
Yes
No

$\beta=$ correlation coefficient; $95 \% \mathrm{CI}=95 \%$ confidence interval. Adjusted for the variables: dental element in mouth, dental prosthesis, information on how to take care of your mouth, last visit to the dentist, any systemic diseases and oral self-perception. Source: Authors.

\section{Discussion}

By proposing to analyze the QoL and its association with sociodemographic and oral health data in noninstitutionalized elderly individuals, this study revealed relevant findings that will be discussed herein. Because there is a great shortage of research that seeks to predict a better QoL in this population, the study has a very important contribution, making it 
pertinent to investigate the association between QoL and oral health aspects (Cohen-Carneiro, Souza-Santos \& Rabelo, 2011; Locker \& Gibson 2005).

Regarding data collection instruments, the WHOQOL-OLD questionnaire is one of the least used instruments, as it has a wide variety of questions and six very distinct domains that make it more complex, but it is the most specific to evaluate the QoL of the elderly. Literature presents in a great amount studies that used the questionnaire of impact produced by the oral condition on the QoL (Oral Health Impact Profile - OHIP 14). Therefore, it evaluates the QoL in relation to the oral conditions. However, the choice in this research for the WHOQOL-OLD as an instrument for QoL measures in the elderly is due to the versatility of the questionnaire. (The Whoqol Group, 1995; Power, Quinn \& Schmidt, 2005).

The present study revealed that the QoL of the elderly was "neither bad nor good", unlike the study by Andrade, Moreira, Martins and Guimarães (2017), which was conducted in Brazil, where the average QoL was satisfactory (88.97), i.e. the elderly had a "good" QoL. This analysis corroborates with Top and Dikmetas (2015), whose study was conducted in Turkey, where the average score indicated that the QoL of the elderly is at the high medium level and considered as "good". However, the studied elderly lived in nursing homes. In the present research, the elderly lived in their homes with their families. Regarding this fact, can the difference in the mean QoL be attributed to it? Or does it only raise a question? Is living with family members the best option to make seniors feel happy? In addition, similar results were found in the studies by Melo et al. (2013) and Alencar, Aragão, Ferreira and Dantas (2010), in which the overall mean of QoL, from the WHOQOL-OLD, was “average". In another study, hypertension and diabetes in the elderly had a negative association with QoL (Borges, Camelier, Oliveira \& Brandão, 2019). In the present study, even though most of the elderly had some type of systemic disease, it was not a predictor of QoL.

After analyzing the oral self-perception scores of the elderly in the present study, we observed that the value obtained by GOHAI classifies the oral health self-perception as poor (low), according to the index classification itself. The obtained value was 25 , and values $<30$ points are classified as "low self-perception". Likewise, the study carried out by Agostinho, Campos and Silveira (2015) provided a score of 29.2, i.e. poor perception of oral health. Worse results were observed in another investigation by Costa, Saintrain and Vieira (2010), in which the GOHAI average was lower (17.53). They resembled the research by Moya, Chappuzeau, Caro and Monsalves (2012), which was performed with elderly individuals. Furthermore, corresponding to this, in the same state, more than half of the elderly had poor perception of their oral health (Santos, 2015). In the present research, more than $90 \%$ of the elderly classified it as poor and only $1.3 \%$ rated their oral health as excellent; however, we did not perform oral clinical evaluation of the elderly. Another study, which analyzed them clinically, presented similar results, that is, the elderly revealed a poor perception regarding oral health, with a high prevalence of periodontal disease and need for prostheses, but the clinical variables were not associated with self-perception (Henrique, 2010). In another investigation, the findings showed that $44.9 \%$ of the elderly had values between 31 and 33 . Thus, there was a moderate perception of their oral health (Fonseca, Almeida \& Silva 2011). Different from these results, with better perceptions of oral health, in the study by Andrade, Lebrão, Santos, Duarte, and Teixeira (2012), most of the elderly rated their oral health as "good". In addition, Vasconcelos et al. (2012) concluded that the elderly's perception of oral health was considered positive in $52 \%$ of them, even with poor oral health.

There was a statistically significant association between the QoL outcome and age in the present study. Older elderly had higher QoL scores, accounting for $25 \%$ of this association. Similar results were found in the study by Kressin Atchis on and Miller (1997), in which they used the GOHAI instrument, and the older seniors showed good self-perception regarding their oral health, which consequently influenced a better QoL. In addition, findings from a study by Gobbens and Remmen (2019) showed that being a woman and being older were negatively associated with QoL. In Europe, the worst QoL was 
related to older ages (Gobbens \& Remmen 2019; Borglin et al., 2006). However, in another study, younger age was related to poorer quality and life in rural elderly individuals in Southern Brazil, compared with people older than 80 years (Master, Molzahn, Fuhrmann, Morais \& Paskulin, 2015; Paskulin, Vianna \& Molzahn, 2009). Our result can be explained by the fact that younger people may feel more hopeful about their lives, allowing themselves to plan and think about the future. This is different of older people, in whom the feeling of hope may be replaced by fear and insecurity.

Another variable that was associated with QoL was daily independence in daily activities, as well as participating in some social activities. When there was less dependence on daily activities and greater participation in social activities with other people, there were higher QoL scores. However, in the study by Bianco, Lopes, Borgato, Silva and Marta (2010), physical and psychological impacts were more intense in the QoL than social impacts. In a study conducted by Chen, Hicks and While (2014), from the WHOQOL-OLD, the elderly who lived alone classified social relations and financial circumstances as causing low satisfaction regarding their QoL. In addition, they found that the elderly's previous occupation and depression had an interaction effect on QoL. One of the explanations, for such results, was that the probability of daily independence is associated with participation in activities. Therefore, if the elderly is independent in daily tasks, they will also be independent in other types of activities, including, and mainly, the associative ones.

The elderly who took more than a year to go to the dentist had a worse quality of life. In addition, the better the elderly's self-perception, the better their QoL. However, from another perspective, the last dentist visit was associated with better self-perception of oral health (Carvalho, Manso, Escoval, Salvado \& Nunes, 2016). Moreover, they were associated with poor QoL in the study by Kotzer et al. (2012), in which adults/elderly presented poor general and oral self-perception and had a dental surgeon appointment less than once a year. A survey conducted in a city of the south of Brazil, near the city where the present study was conducted, showed that the elderly with higher levels of life satisfaction had a better perception of their oral health (Rigo, Basso, Pauli, Cericato, Paranhos \& Garbin, 2015). Moreover, having a perceived unmet need for dental treatment and expressing a lack of confidence in the dentist were predictors of poor oral health-related QoL (Muirhead, Marcenes \& Wright, 2013).

Some variables, which could not be analyzed in this research, but are of great relevance, are information related to income and education of the elderly. In other studies, it was found that more years of schooling, as well as having completed high school, are associated with better QoL scores (Master et al., 2015; Gobbens et al., 2010). In addition, Moreira et al. (2005) found that the main barriers for the elderly to have greater access to dental services were low education and income, in addition to the scarcity of public oral health services. Importantly, in this study, the lower frequency of visits to a professional dentist showed a worsening in the QoL.

One of the limitations of this study was the lack of oral clinical examination in order to verify the number of teeth present in the mouth and the clinical conditions of each elderly. However, the use of dental prostheses and the perception of their oral health were verified. Another limitation was the fact that the study design is cross-sectional and does not allow the determination of cause and effect, considering that the evaluated data have no temporality and are valid at the time of research data collection.

Despite a sample loss of $20 \%$, this study presented a probabilistic sample from a sample calculation, which guarantees the elderly's representativeness evaluated by extrapolating to the entire non-institutionalized population in the same age group. The present work has a great contribution to the area of collective oral health, because it evidenced important data regarding the elderly's QoL. More in-depth knowledge of the aspects, which help to improve the QoL of this population, contributes to a more effective planning of oral health promotion in these elderly individuals. The desire of any society is that individuals may achieve aging with dignity, but this will only be done if we know how to maintain a good QoL (Fonseca et al., 2011). 


\section{Conclusion}

The overall mean QoL was rated as neither bad nor good according to the WHOQOL-OLD.

The findings showed that the being older, being dependent in life and non-participating in social activities, as well as no visiting the dentist last year were predictors of a worst QoL for the elderly, however, good self-perception of oral health was a predictor of better QoL.

The present study revealed important associations, which leads us to reflect on the challenge of improving QoL scores. Thus, the authors suggest the implementation of guidelines and interventions by public health managers in improving the QoL of the city's elderly. We suggest more research with longitudinal design and other variables, in order to verify the impact on QoL in the long term.

\section{References}

Agostinho, A. M. G., Campos, M. L. \& Silveira, J. L. G. C. (2015). Edentulism, use of prosthesis and self-perception of oral health in the elderly. Rev Odontol UNESP, 44, 74-79.

Alencar, N. A., Aragão J. C. B., Ferreira, M. A. \& Dantas, E. H. M. (2010). Assesment of the quality of life elderly women living in urban and rural environments. Rev. Bras. Gerontol,13, 103-109.

Andrade, F. B., Lebrão, M. L., Santos, J. L. F., Duarte, Y. A. O. \& Teixeira, D. S. C. (2012). Factors related to poor self-perceived oral health among community-dwelling elderly individuals in São Paulo, Brazil. Cad. Saúde Pública, 28, 1965-1975.

Andrade, I. A., Moreira, J. C. A, Martins, L. C. \& Guimarães C. P. (2017). Elderly health training for UBS Citrolândia's community health workers in BetimMG: report of an extensionist practice. Sinapse Múltipla, 6, 267-272.

Atchison, K. A. \& Dolan, T. A. (1990). Development of the geriatric oral health assessment index. J Dent Educ. 54, 680-686.

Bianco, V. C., Lopes, E. S., Borgato M. H., Silva P. M. \& Marta S. N. (2010). The impact on life quality due to oral condition in people fifty years or above. Cien Saude Colet, 15, 2165-2172.

Boggatz T. (2016). Quality of life in old age - a concept analysis. International Journal of Older People Nursing, $11,55-69$.

Borges, J. E. S., Camelier, A. A., Oliveira, L. V. F. \& Brandão, G. S. (2019). Quality of life of elderly hypertensive and diabetics of the community: a observational study. Rev. Pesqui. Fisioter, 9, 74-84.

Borglin, G., Jakobsson, U., Edberg, A. K. \& Hallberg, I. R. (2006). Older people in Sweden with various degrees of present quality of life: their health, social support, everyday activities and sense of coherence. Health Soc Care Commun, 14, 136-146.

Bulgareli, J. V., Faria, E. T., CortellazziI, K. L., Guerra, L. M., Meneghim, M. D. C. \& Ambrosano, G. M. B et al. (2018). Factors that influence the impact of oral health on daily activities of adolescents, adults and the elderly. Rev Saude Publica Health, 52 (44), Epub April 12.

Carvalho, C., Manso, A. C. A., Salvado, F. \& Nunes, C. (2013). Translation and validation of the portuguese version of Geriatric Oral Health Assessment Index (GOHAI). Rev. Port. Saúde Pública. 31, 153-159.

Carvalho, C., Manso, A. C., Escoval, A., Salvado, F. \& Nunes, C. (2016). Self-perception of oral health in older adults from an urban population in Lisbon, Portugal. Rev Saude Publica, 50, 1-9.

Chen, Y., Hicks A. \& While A. E. (2014). Quality of life and related factors: a questionnaire survey of older people living alone in Mainland China. Qual. Life Res, 23, 1593-1602.

Cohen-Carneiro, F., Souza-Santos, R. \& Rabelo, M. A. B. (2011). Quality of life related to oral health: contribution from social factors. Ciên. Saúde Col, 16, 1007-1115.

Costa, E. H. M., Saintrain, M. V. L. \& Vieira, A. P. G. F. (2010). Self-perception of oral health condition of the institutionalized and non-institutionalized elders. Ciên. Saúde Col, 15, 2925-30.

Fleck, M. P. A, Louzada, S., Xavier, M., Chachamovich, E., Vieira, G., \& Santos, L. et al. (2000). Application of the Portuguese version of the abbreviated instrument of quality life WHOQOL-bref. Rev Saude Publica, 34, 178-183.

Fleck, M. P. A., Chachamovich, E. \& Trentini, C. M. (2003). WHOQOL-OLD Project: method and focus group results in Brazil. Rev Saude Publica, 37, 793799.

Fonseca, P. H. A., Almeida, A. M. \& Silva, A. M. (2011). Oral health conditions in institutionalized elderly population. RGO - Rev Gaúcha Odontol, 59, 193200.

Gobbens, R. J. J. \& Remmen, R. (2019). The effects of sociodemographic factors on quality of life among people aged 50 years or older are not unequivocal: comparing SF-12, WHOQOL-BREF, and WHOQOL-OLD. Clin. Intervent, 14, 231-239. 
Research, Society and Development, v. 10, n. 2, e42310212645, 2021

(CC BY 4.0) | ISSN 2525-3409 | DOI: http://dx.doi.org/10.33448/rsd-v10i2.12645

Gobbens, R. J. J., VanAssen, M. A. L. M, Luijkx, K. G, Wijnen-Sponselee, M. T. \& Schols J. M. G. A. (2010). The Tilburg Frailty Indicator: psychometrics properties. J Am Med Dir Assoc, 11, 344-55.

Henriques, J. C. C. S. (2010). Impact of edentulism on the quality of life of two Brazilian individuals. Acta Odontol. Venezolana, $51,1-7$.

IBGE. (2018). Instituto Brasileiro de Geografia e Estatística.

Conheça as Cidade do Brasil. Marau. Disponível em: <https://cidades.ibge.gov.br/brasil/rs/Marau/panorama >. Acesso em: 20 jan 2018.

Kotzer, R. D., Lawrence, H. P., Clovis, J. B., \& Matthews, D. C. (2012). Oral health-related quality of life in an aging Canadian population. Health and Quality of Life Outcomes. 10, 1-12.

Kressin, N. R., Atchison, K. A. \& Miller, D. R. (1997). Comparing the impact of oral disease in two populations of older adults: application of the geriatric oral health assessment index. J Public Health Dent, 57, 224-232.

Lebrão, M. L. \& Laurenti, R. (2005). Well-Being and aging: the SABE Study in São Paulo, Brazil. Rev Bras Epidemiol, 8, $127-168$.

Locker, D. \& Gibson, B. (2005). Discrepancie between self-ratings of and satisfaction with oral health in two older adult populations. Comunnity Dent Oral Epidemiol, 33, 280-288.

Malta, M., Cardoso, L. O., Bastos, F. I, Magnanini, M. M. F. \& Silva, C. M. F. P. (2010). STROBE Initiative: Subsidies for Reporting Observational Studies. Rev Saude Publica, 44, 559-565.

Martins, A. M. E. B. L., Barreto, S. M. \& Pordeus, I. A. (2009). Oral Health self-assessment in the elderly: analysis based on a multidimensional model. Cad. Saúde Pública, 25, 421-435.

Master, G. G., Molzahn, A, Fuhrmann, A. C., Morais, E. P., \& Paskulin, L. M. (2015). Quality of life of older adults in rural southern Brazil. Rural Remote Health. 15, 1-15.

Melo, R. L. P., Eutálio, M. C, Silva, H. D. M, Silva-Filho, J. M \& Gonzaga, P. S. (2013). Sense of life, funcional dependece and quality of life in the elderly. Rev. Bras. Geriatr. Gerontol, 16, 239-250.

Moreira, R. S., Nico, L. S. \& Sousa, M. L. R. (2009). Factors associated with subjective need for dental treatment in elderly Brazilians. Dent Care Oral Heal, $25,2661-271$

Moreira, R. S., Nico, L. S., Tomita, N. E., \& Ruiz, T. (2005). Oral health of Brazilian elderly: a systematic review of epidemiologic status and dental care access. Cad. Saúde Pública, 21, 1665-1675.

Moya P., Chappuzeau E., Caro J. C., \& Monsalves M. J. (2012). Oral health situation and quality of life of older adults. Rev Estomatol Herediana, 22, 197202.

Muirhead, V. E., Marcenes, W., \& Wright, D. (2013). Do health provider-patient relationships matter? Exploring dentist-patient relationship and oral healthrelated quality of life in older people. Age and Ageing, 43, 399-405.

Paskulin, L., Vianna, L., \& Molzahn, A. E. (2009). Factors associated with quality of life of Brazilian older adults. Int Nurs Rev, 56, 109-115.

Power, M., Quinn, K. \& Schmidt, S. (2005). WHOQOL-OLD group Development of the WHOQOL-Old module. Qual Life Res., 14, 2197-2214.

Rigo L., Basso K., Pauli J., Cericato G. O., Paranhos L. R, \& Garbin R. R. (2015). Satisfaction with life, dental experience and self-perception of health among the elderly. Ciên. e Saúde Col. 20, 3681-3688.

Santos, C. M. (2015). Applicability teste of a modelo f oral health-related quality of life. Cad. Saúde Pública, 31,1871-1880.

THE WHOQOL GROUP (1995). The World Health Organization quality of life assessment (WHOQOL): position paper from the World Health Organization. Social Sci Med, 41, 1403-1409.

Top, M. \& Dikmetas, E. (2015). Quality of life and attitudes to ageing in Turkish older adults at old people's homes. Health Expectation, 18, 288-300.

Vasconcelos, L. C. A, Prado Jr., R. R, Teles, J. B. M., \& Mendes, R. F. (2012). Self-perceived oral health among elderly individuals in a medium-sized city in Northeast Brazil. Cad. Saúde Pública, 28, 1101-1110. 